PROBLEMS

OF EDUCATION IN THE $21^{\text {st }}$ CENTURY Vol. 79 , No. 3, 2021

412

\title{
INTERTWINING MATHEMATICAL MODELING WITH ENVIRONMENTAL ISSUES
}

\author{
Ramazan Gürbüz \\ Adıyaman University, Turkey \\ E-mail: rgurbuz@outlook.com \\ Muammer Çalık \\ Trabzon University, Turkey \\ E-mail: muammer38@hotmail.com
}

\begin{abstract}
Since contemporary learning theories, strategies and models offer the interdisciplinary approach, educators need new pedagogical alternative ways to attain it in practicum. For this reason, the current research aimed to illustrate how to intertwine mathematical modeling with an environmental issue that recruits waste management (e.g., reuse-recycle-reduce) to live an environmentally friendly lifestyle. Through a case study research, 6 seventh-grade students (3 females and 3 males; aged 13-14) voluntarily participated in the research. The researchers videotaped and analyzed all interactive learning processes to elicit the students' environmental dialogues. The results indicated that the interdisciplinary mathematical modeling afforded the students to acquire the targeted environmental concepts/issues and somewhat supported their arguments. Since the current research illustrates an alternative pedagogy to integrate sciencelenvironmental education into mathematics, it may be used to facilitate dissemination and applicability of the STEM education.
\end{abstract}

Keywords: environmental issues, interdisciplinary approach, mathematical modeling

\section{Introduction}

Population growth and scientific/technological advances have globally influenced food production, energy use, climate, land use, air, and water quality. Imbalanced interactions between humans and their environments have yielded to anthropogenic environmental problems (e.g., Atmaca et al., 2020; Er Nas \& Çalık, 2018) that threaten the restorative capacity of natural ecosystems. For example, people, who are unaware of their own environmental and social responsibilities, use environmental resources as if they were infinite (Çalık \& Eames, 2012). Such anthropogenic activities and environmental degradation pose a major ecologic threat for sustainable development (Montgomery, 2007) and natural ecosystems (e.g., forestry ecosystems) (e.g., Er Nas \& Çalık, 2018). These concerns need to be resolved through the recognition of the interconnections amongst environment, social behavior, cultural histories, and economic processes (Çalık \& Eames, 2012).

To minimize environmental damage, people need to be informed and educated about environmental problems. This calls for their active participation in developing solutions to environmental issues. Thus, they can behave responsibly towards the environment in which they live. Given the enormous publicity associated with environmental issues such as global warming, environmental education can be employed to change people's perceptions, attitudes, and habits (Bilianska \& Yaroshenko, 2020; Çalık, 2009). This means that formal and informal 
education plays a significant role at accomplishing environmental education, environmental sustainability, and sustainable development (e.g., Deveci \& Karteri, 2021). For example, in Turkey, newly released curricula, which integrate environmental education into relevant issues, purpose to educate well-qualified and responsible citizens for environmental education by means of student-centered learning strategies (e.g., Çalık, 2009; Deveci \& Karteri, 2021). In fact, such a learning strategy/environment necessitates having well-qualified teachers with knowledge of pedagogical strategies for environmental education (e.g., Çalık, 2009). That is, teachers, who have a good level of environmental literacy and pedagogical content knowledge, think about how to teach environmental concepts/issues effectively (Çalık \& Aytar, 2013; Deveci \& Karteri, 2021).

\section{Research Problem}

Even though contemporary learning theories, strategies and models offer the interdisciplinary approaches, educators have still possessed some educational problems at collaboratively working with each other and reflecting various disciplines. For example, although Science, Technology, Engineering, and Mathematics (STEM) education asks for intertwining different disciplines with each other, the STEM studies have generally had some deficiencies at correlating subjects/disciplines (Doğan et al., 2019; Gürbüz et al., 2018; Herdem \& Ünal, 2018; Ormanc1, 2020). Moreover, since the interdisciplinary approach covers different subjects, skills and collaborations, educators need higher-order thinking and management/ leadership skills. For this reason, mathematics and science teachers/educators have still had some pitfalls at practically implementing STEM education and/or interdisciplinary approach into their classes (Gürbüz et al., 2018). Therefore, educators, teachers and researchers need new pedagogical alternative ways to attain the interdisciplinary approach in practicum (Gürbüz et al., 2018; Milli Eğitim Bakanlığı, 2016). In that case, intertwining mathematical modeling with environmental issues may act as a catalyst that facilitates applicability and feasibility of the interdisciplinary approach and/or STEM education (Doğan et al., 2019; Gürbüz et al., 2018).

\section{Research Focus}

Because Turkey does not possess a teacher education program in environmental education and STEM education, teachers need to see how to integrate environmental issues and mathematical modeling into their classes and/or lesson plans. For example, science teachers, who are generally familiar with environmental issues, can easily interpret related goals of science curriculum and integrate environmental issues into their classes and/or lesson plans. But this may be difficult for mathematics teachers. Likewise, science teachers may have difficulties at using mathematical modeling in science learning. For this reason, they need to be informed about how to intertwine mathematical modeling with environmental issues. Phrased differently, integration of environmental issues into mathematics education may be an alternative pedagogical way to achieve a better interdisciplinary approach.

\section{Interdisciplinary Mathematical Modeling}

Mathematical modeling, as one of the $21^{\text {st }}$ century mathematics competencies (Dewanti et al., 2020), involves real-life problems and concentrates on contextually minds-on activities that stimulate students' mental models or cognitive scaffolds (e.g., Berry \& Houston, 1995; Doğan et al., 2019; Gürbüz et al., 2019; Lesh \& Doerr, 2003). Taking related literature into consideration, Doğan et al. (2019) has released a theoretical framework for the interdisciplinary mathematical modeling (see Figure 1).

\author{
PROBLEMS \\ OF EDUCATION \\ IN THE $21^{\text {st }}$ CENTURY \\ Vol. 79, No. 3, 2021 \\ 413
}


PROBLEMS

OF EDUCATION IN THE $21^{\text {st }}$ CENTURY Vol. 79, No. 3, 2021

414

Figure 1

Interdisciplinary Mathematical Modeling Process of Mathematics and Science (adopted from Doğan et al., 2019, p.634)

REAL WORLD

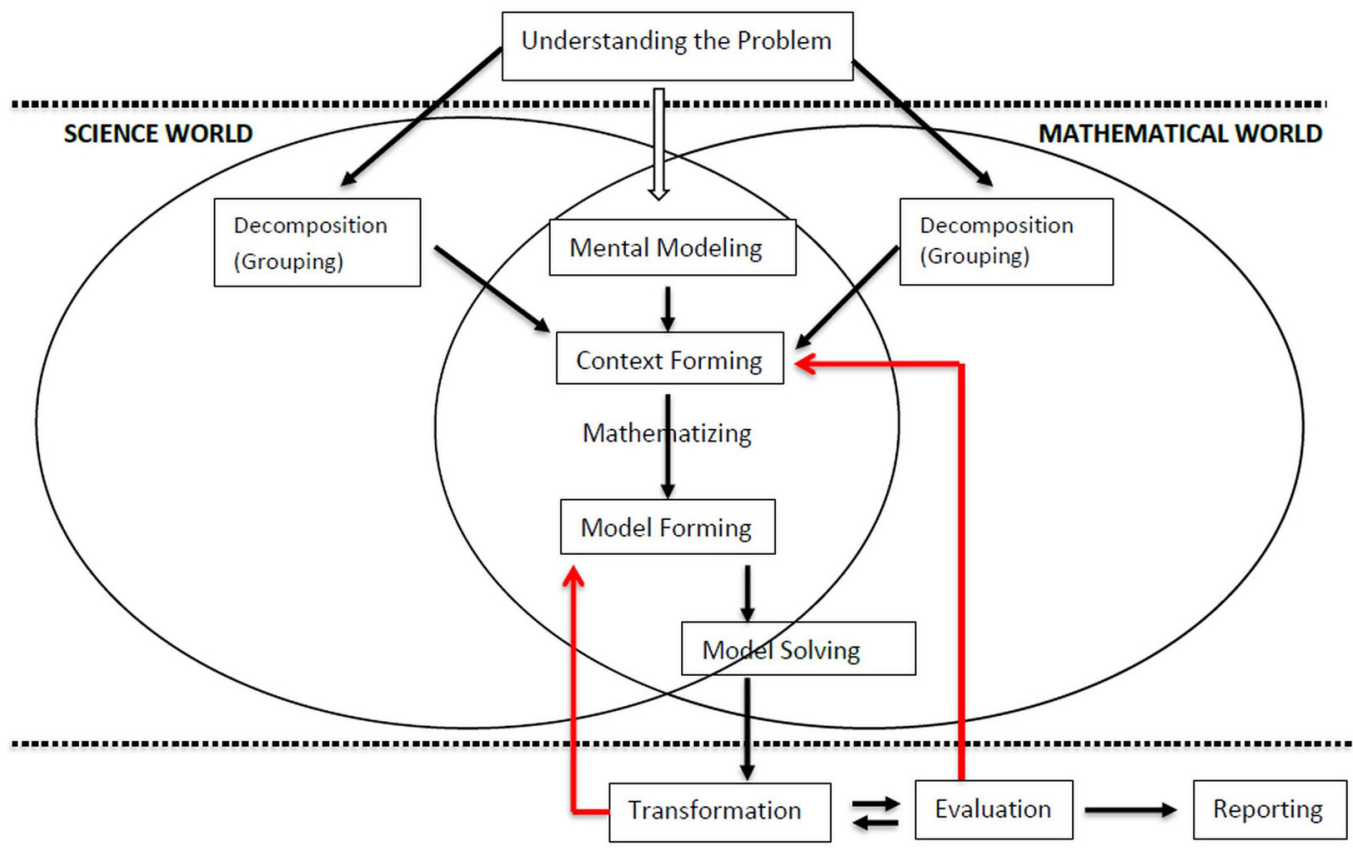

REAL WORLD

As seen from Figure 1, the interdisciplinary mathematical modeling, as a theoretical framework, firstly asks students to understand relevant problem, which embeds science (e.g., chemistry, physics, biology, environmental sciences) within mathematics. Then, they are encouraged to differentiate necessary variables from unnecessary ones by identifying their own problem(s). Given the nature of relevant problem, the "mental modeling" stage calls them for denoting their own hypothesis and appropriate plans. Thus, they are able to classify simplified concepts under "science and mathematical world" (called decomposition/grouping) and generate a context for the interdisciplinary mathematical modeling (named context forming). After noticing the context, students are expected to create their own mathematical model(s) (called model forming). Later, they need to provide their own mathematical solutions by means of their existing mathematical knowledge (named model solving). Given their (possible) results, students are requested to associate their models/solutions with real-life issues/problems/ contexts (called transformation) and test the validity and applicability of their solutions (named evaluation). If students are satisfied with their created models that functionally respond reallife issues/problems/contexts under investigation, they summarize their own problem-solving processes/results and prepare their own reports (called reporting). Meanwhile, the foregoing theoretical framework flexibly allows any proper transition between the interdisciplinary mathematical modeling processes. For example, students may jump into the "mental modeling" stage without grouping the related concepts in science (e.g., chemistry, physics, biology, environmental sciences) and mathematical world. Likewise, if they contextually find their models inappropriate or inapplicable for the real world, they may return to the "model forming" or "context forming" stage (Doğan et al., 2019). 
Given the aforementioned issues, the current research aimed to illustrate how to intertwine mathematical modeling with an environmental issue that recruits waste management (e.g., reuse-recycle-reduce) to live an environmentally friendly lifestyle (Iliopoulou, 2018a,b).

The following research questions guided the current research:

1. How can the interdisciplinary mathematical modeling be conducted with seventhgrade students?

2. Which environmental themes and categories appear during the implementation of the interdisciplinary mathematical modeling?

\section{Research Methodology}

\section{General Background}

Through a case study research, the current research deeply examined the participants' dialogues of environmental issues while they were engaging the interdisciplinary mathematical modeling in their small groups. That is, the current research, which viewed each group (3 by 3 ) as a case study, strived to critically handle the interdisciplinary mathematical modeling within a clear set of propositions, e.g., environmental issues/education (Yin, 2003).

\section{Participants}

6 seventh-grade students (3 females and 3 males; aged 13-14), who were purposefully drawn from a state middle school in the city of Adiyaman, Turkey, voluntarily participated in the research during the fall semester of the 2018-2019 academic year. All participants' previous mathematics and science performances/scores fell into the average level.

\section{Data Collection and Analysis}

All interactive learning processes were videotaped to elicit the students' environmental dialogues. Then, the researchers independently identified environmental categories and themes by means of verbatim transcriptions (Merriam, 1998; Yin, 2003). Interrater consistency value was found to be .71, which is slightly higher than the acceptable reliability coefficient $(.70)$ suggested by Hair et al. 2006). Any disagreement was solved through negotiation.

\section{Procedure}

A mathematics teacher and a science teacher, who participated in a 36-hour in-service education on the interdisciplinary mathematical modeling (this is of interest in another paper), collaboratively worked and then carried out the activity "Plastic Bottle." Prior to the activity, the teachers asked the students to create their own small groups of 3. Later, they handed out the news entitled "plastic bottle instead of brick" to the students and requested them to read it very carefully. Then, the mathematics teacher asked provocative questions (e.g., What science and mathematics concepts do you think the news emphasize? Why is the house in the news environmentally friendly? What do you think about Andreas Froese's waste management?) to stimulate their learning curiosity and activate their pre-existing knowledge. Hence, such a procedure not only created a "need-to-know" basis for advanced concepts but also promoted the students to learn related fundamental concepts prior to solving the problem. 
Ramazan GÜRBÜZ, Muammer ÇALIK. Intertwining mathematical modeling with environmental issues

PROBLEMS

OF EDUCATION

IN THE $21^{\text {st }}$ CENTURY

Vol. 79, No. 3,2021

416

Figure 2

The News Entitled "Plastic bottle instead of brick"

\section{PLASTIC BOTTLE INSTEAD OF BRICK}

About 80 percent of the plastic bottles, which will have not destroyed for centuries, are thrown into the sea. Can you imagine a house made of plastic bottles? Andreas Froese carried out his crazy idea in Africa.

Empty plastic bottles are filled with sand and rubble. The bottles stacked on top of each other are plastered with slime and mortar. Then, the building is fixed with plastic cords Through a plastic house project, Andreas Froese purposes to not only protect nature but also offers a life perspective for poor people:

"In the beginning, people are more suspicious. It's hard to imagine, so they wonder and come to construction. Then, we can show them that our construction material, a normal plastic bottle, is more durable than a brick. Also, it is more resistant to pressure and impact."

To build the house, specially trained employees get the necessary bottles from hotels, restaurants and people. Electricity is provided by solar panels and each house is planned to have its own wastewater and drinking water system.

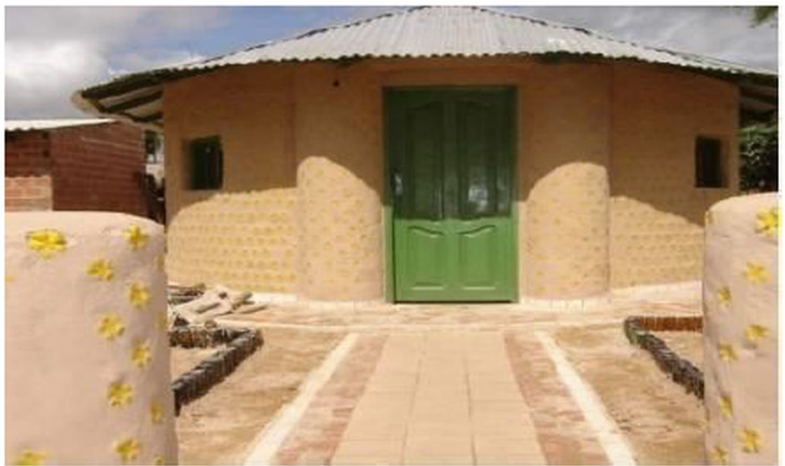

Building a house made of plastic bottles is more economic. In Nigeria, a brick costs about a third of what an employee earns a day. But the real problem is financing such projects. Despite the success of environmental projects, finding financial sponsors is very difficult.

Buildings made of plastic bottles look like adobe houses. When outside is cold, its inside is hot. Also, it offers a cool atmosphere in the summer heat. Further, these houses, which use plastic bottles in this sector, contributes to protecting oil resources. Because of interestingly designed houses, they also stimulates tourism. In addition, school-aged children, who work during the construction, are part of a project aimed at addressing environmental problems.

The teachers passed out the problem sheet entitled "Building environmentally friendly constructions with plastic bottles" to the students and asked them to read it very carefully to comprehend the problem. 


\section{Figure 3}

The Problem Sheet Entitled "Building environmentally friendly constructions with plastic

\section{BUILDING ENVIRONMENTALLY FRIENDLY CONSTRUCTIONS WITH PLASTIC BOTTLES}

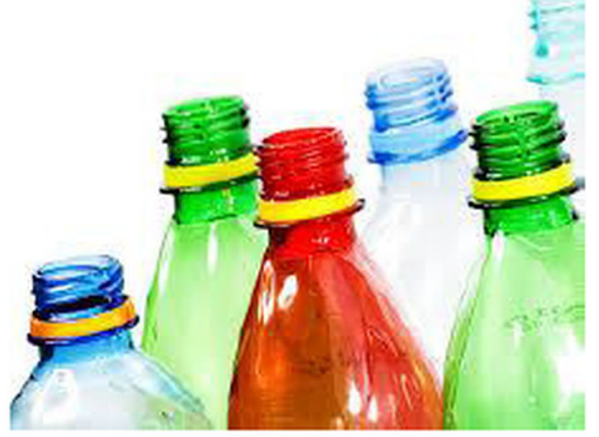

Over a million animals lose their lives every year because of plastic consumption. Plastic bottles, which are torn apart by external influences, damage nature and natural life as micro-plastics. Unless the unconscious use of plastic bottles is prevented, plastic bottles will continue to threaten nature and life. However, different alternative ways are available to reuse them. For example, plastic bottles are used to build durable and low-cost homes, especially in underdeveloping countries.

Considering socio-cultural life conditions of our country, the use of constructions made of plastic bottles is not very common in the construction sector. However, it is possible to build such constructions at social areas as parks and school gardens to emphasize environmental pollution in our country and make people aware of waste management, for instance, 'reuse.'

The most effective ways to create environmentally friendly habitats and prevent environmental pollution are "recycle, reuse and reduce." Given the aforementioned issues, the "Environmental constructions with Reusable Materials" project requires you to build a playhouse your school garden. You are asked to prepare a report responding the following questions "How many plastic bottles do you need to build this playhouse?" and "How does such a house make a contribution to nature?"

In the stage "Understanding the problem," the teachers encouraged the students to notice the problem called "plastic bottles instead of bricks," and think about how to design an effective playhouse. Thus, the students could grasp related concepts (i.e., reuse, recycle, reduce) of waste management and comprehend how such constructions result in a better waste management to save the Earth. The stage "Mental modeling" required them to look for the relevant reports about plastic bottles (e.g., some countries throw away 2.5 million plastic bottles per hour) and duration of decomposition of any plastic bottle in nature (e.g., 500 years). Hence, the students could perceive that leaving plastic bottles to the environment mainly damages the nature. Further, they could create their own mental models to design their playhouses and consider how to effectively minimize the number of plastic bottles in nature (e.g., the use of 0.5 -liter plastic bottles in their own playhouses). Also, the teachers fostered the students to realize environmental (e.g., environment, environmental pollution, environmentally friendly living constructions, recycling, reuse and reduce) and mathematical concepts/terms (e.g., mathematically length measurement, field measurement units and transformations, properties of geometric objects, calculation of areas of geometric shapes) for the stage "decomposition (grouping)." Further, the stage "context forming," which called the students for calculating the number of plastic bottles to design the playhouse, generated an environmental context through the interdisciplinary mathematical modeling. That is, the students could notice related concepts of waste management (e.g., reuse) and prioritize building environmentally friendly 
PROBLEMS

OF EDUCATION

IN THE $21^{\text {st }}$ CENTURY

Vol. 79, No. 3,2021

418

constructions. Thus, they could see how to reduce any negative effect of the use of plastic bottles on nature, soil, and water (as the context).

The teachers asked the students to design their own playhouse models (the stage "model forming"). For instance, the students could design a $3 \mathrm{~m} \times 3 \mathrm{~m}$ floor to enable several students to play in the playhouse at the same time. Further, they could set the height of the playhouse at $2.5 \mathrm{~m}$ given the average height of a room $(2.60 \mathrm{~m})$. A sample house design (with a door and one window for each of three identical facades) and its sizes are shown in Figure 4A.

\section{Figure 4}

Sample Mathematical Models

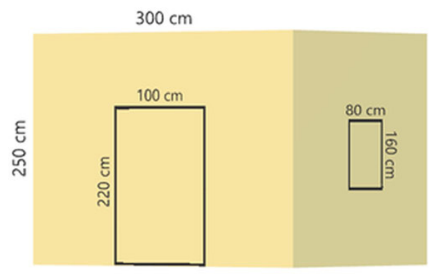

A

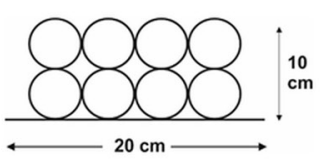

B

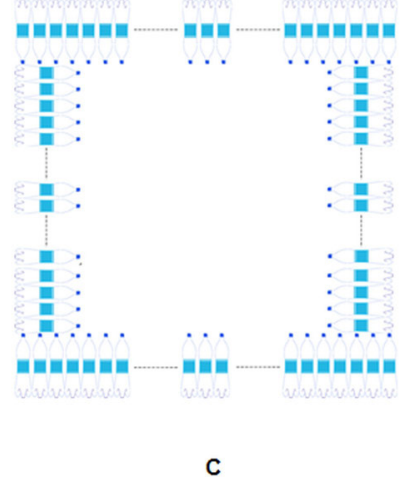

The students planned to collect 0.5 -liter plastic bottles of water, which are mostly used in daily life and easily accessible. Then, they measured the size and base diameter of a plastic bottle and thought about directions of mouth and base of the plastic bottle. For instance, they placed mouth of the plastic bottle towards inside and its base to outside when bonding the walls (see Figure 4B). Further, they inquired how to increase thermal insulation and viewed Figure $4 \mathrm{C}$ as a proper construction that increases thermal insulation and reduces heat-loss. After completing the design of the playhouse, they initially calculated the number of plastic bottles as if there were no doors and windows. Later, they subtracted areas of the door and windows from the total number (see Figure 5 for a sample calculation). 


\section{Figure 5}

For a row on front and rear facade, they need $2 \times(300 \mathrm{~cm} \div 5 \mathrm{~cm})=120$ plastic bottles.

For a row on side facade, they need $2 \times(260 \mathrm{~cm} \div 5 \mathrm{~cm})=104$ plastic bottles.

Without door and windows, they need a total of $(250 \mathrm{~cm} \div 5 \mathrm{~cm}) \times 120=6000$ plastic bottles for front and rear facades.

Without windows, they need a total of $(250 \mathrm{~cm} \div 5 \mathrm{~cm}) \times 104=5200$ plastic bottles for side facades.

To build the playhouse, they need to collect a total of $6000+5200=11200$ plastic bottles before subtracting the areas of the

door and windows.

Because the door's sizes are $100 \mathrm{~cm} \times 220 \mathrm{~cm}$, they need to subtract $(100 \div 5) \times(220 \div 5)=880$ plastic bottles from the total number.

Similarly, since the sizes of the identical windows are $80 \mathrm{~cm} \times 160 \mathrm{~cm}$, they need to subtract $3 \times(80 \div 5) \times(160 \div 5)=1536$

plastic bottles from the total number.

Overall, the playhouse can be built with a total of $11200-880-1536=8784$ plastic bottles.

The students planned to collect an average of 9000 plastic bottles in case some of them might be unusable. Hence, they could differentiate the concept "recycle" from the one "reuse." Moreover, the teachers fostered the students to discuss about the questions "How does such a playhouse made of plastic bottles impede environmental pollution?”, "How does it make a contribution to public health, natural life and national economy?", "How does it minimize microplastics that threaten water creatures and human lives?" and "Which type (e.g., reuse, recycle, reuse) of waste management is more feasible for us and natural life cycles?" Hence, they had an opportunity to generate their own arguments and defend their reasons of environmental issues, i.e., environmental pollution, waste management, microplastics.

The stage "transformation" guided the students to pose their advanced and transformable thinking skills of real-life issues. For example, the teachers used the following questions "How do environmentally friendly houses built by Andreas Froese or your designed playhouses protect nature?", "How do they bring new insights and/or bright ideas for people?" and "Do you think your model has any minimal calculation deviation?". Hence, the students could notice any difference/deviation between a theoretical calculation (that neglects such issues as flexibility of the plastic bottle and mortar thickness) and a real case.

During the stage "evaluation," the teachers encouraged the students to consider their learning processes of the interdisciplinary mathematical modeling and make their selfassessments. Thereby, the students could evaluate many different designs and re-think about how the playhouse made of plastic bottles would contribute to environmental education/waste management. Finally, the teachers required the students to concisely outline their own problemsolving processes/results and prepare their own reports (the stage "reporting”).

\section{Research Results}

As seen from Table 1, the students' dialogues appeared in 11 categories under three themes (protecting environment/nature, waste/save and informing society about environmental issues). Both of the groups emphasized the categories "pollution, protecting soil/livings, making a contribution to environmental protection, reusing, preferring a large-size plastic bottle, reducing consumption, and energy saving" while solving the problem "Building environmentally friendly constructions with plastic bottles." Also, while Group 1 only referred to the categories "reducing the use of oil and global warming," Group 2 solely dealt with the categories "giving a message and raising environmental awareness." 
Ramazan GÜRBÜZ, Muammer ÇALIK. Intertwining mathematical modeling with environmental issues

PROBLEMS

OF EDUCATION

IN THE $21^{\text {st }}$ CENTURY

Vol. 79 , No. 3, 2021

420

Table 1

A Summary of Environmental Categories and Themes Based on the Students' Statements

\begin{tabular}{|c|c|c|c|c|}
\hline Themes & Categories & Sample statements & Group 1 & Group 2 \\
\hline \multirow{5}{*}{ 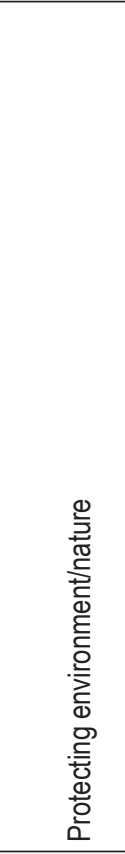 } & $\begin{array}{l}\text { Reducing the use } \\
\text { of oil }\end{array}$ & $\begin{array}{l}\text { By reducing the production amount of plastic, we } \\
\text { are able to decrease the consumption of oil-based } \\
\text { products/goods. For example, if half-liter of oil } \\
\text { is used to produce a plastic bottle, a decrease } \\
\text { in the production of plastic bottles reduces the } \\
\text { consumption of oil. }\end{array}$ & $\checkmark$ & \\
\hline & Pollution & $\begin{array}{l}\text {...throwing away these plastic bottles randomly } \\
\text { to the environment/nature, we result in visual } \\
\text { pollution. By picking them up, we are able to } \\
\text { prevent visual pollution. }\end{array}$ & $\checkmark$ & \\
\hline & Protecting soil/livings & $\begin{array}{l}\text { Given the news of plastic bottles, their } \\
\text { decomposition process takes about } 4000 \text { years. In } \\
\text { this period, they damage soil and livings in the soil. } \\
\text { By building a playhouse made of plastic bottles, we } \\
\text { can minimize their negative effects/damages on } \\
\text { nature and animals. }\end{array}$ & & \\
\hline & Global warming & $\begin{array}{l}\text {...the more plastic production decreases, the more } \\
\text { global warming reduces too. }\end{array}$ & $\checkmark$ & \\
\hline & $\begin{array}{l}\text { Making a contribution } \\
\text { to environmental } \\
\text { protection }\end{array}$ & $\begin{array}{l}\text { By building a playhouse made of plastic bottles at } \\
\text { our own school, we will not only do a good job for } \\
\text { younger children but also make a great contribution } \\
\text { to environmental protection. }\end{array}$ & & \\
\hline \multirow[b]{4}{*}{ 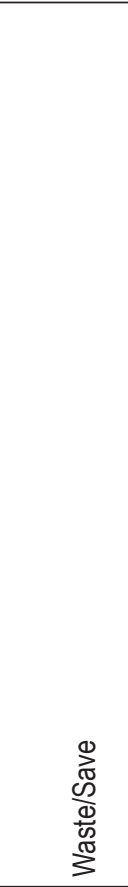 } & Reusing & $\begin{array}{l}\text {...when we build a playhouse made of plastic } \\
\text { bottles for little children, we re-use them instead of } \\
\text { throwing them into the bin. Thus, we can not only } \\
\text { clean our environment/nature but also impede their } \\
\text { adverse effect(s) on the nature. }\end{array}$ & & \\
\hline & $\begin{array}{l}\text { Preferring a large-size } \\
\text { plastic bottle }\end{array}$ & $\begin{array}{l}\text {...if we use large-size plastic bottles, they can } \\
\text { hinder the effect of hot air on the house [thermal } \\
\text { insulation]. Thus, the houses will not be very hot } \\
\text { alike those in African countries. Phrased differently, } \\
\text { the climate and air of the houses [made of large- } \\
\text { size plastic bottles] will be better [than those with } \\
\text { small-size plastic bottles]. }\end{array}$ & $\checkmark$ & \\
\hline & $\begin{array}{l}\text { Reducing } \\
\text { consumption }\end{array}$ & $\begin{array}{l}\text {...we can decrease the number of plastic bottles } \\
\text { that pollute the nature. Further, we can contribute } \\
\text { to save the nature by reducing the consumption of } \\
\text { plastic bottles. Moreover, reducing the number of } \\
\text { plastics bottles, which will be decomposed into the } \\
\text { soil, will also increase the fertility of the soil. }\end{array}$ & $\sqrt{ }$ & \\
\hline & Energy saving & $\begin{array}{l}\text {...building the playhouse made of plastics bottles } \\
\text { enables us to use minimal energy. That is, it results } \\
\text { in energy saving. }\end{array}$ & $\checkmark$ & \\
\hline \multirow{2}{*}{ 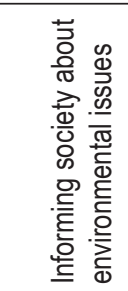 } & Giving a message & $\begin{array}{l}\text { This building gives an environmental message to } \\
\text { the people, who see it. }\end{array}$ & & \\
\hline & $\begin{array}{l}\text { Raising environmental } \\
\text { awareness }\end{array}$ & $\begin{array}{l}\text {...if we build this playhouse made of plastic bottles } \\
\text { to social areas [playland, garden, park], which } \\
\text { people often visit, this building informs them } \\
\text { about environmental issues and stimulates their } \\
\text { environmental awareness of waste management. }\end{array}$ & & \\
\hline
\end{tabular}




\section{Discussion}

As seen from Table 1, the students employed mathematical modeling and relevant environmental concepts/issues together while solving the problem. This means that the current research afforded them to intertwine mathematics with science/environmental education. This may be seen as an indicator of its applicability for seventh-grade students. Phrased differently, the research results indicated that the interdisciplinary mathematical modeling tended to support contextual learning (context-based learning) and higher-order thinking skills (e.g., problem solving, $21^{\text {st }}$ century skills, mathematical thinking, reasoning abilities, creative thinking, and scientific literacy). Further, it challenged the abstractness and rote learning of school mathematics and science (Cedere et al., 2020; Davison et al. 1995; Doğan et al., 2019; Ültay \& Çalik, 2016). Hence, it attempted to enhance the seventh-grade students' familiarity with the interdisciplinary mathematical modeling and environmental issues. Since conventional/ procedural problem-solving habits are not enough to produce effective solutions for reallife issues, the students seem to have noticed this inability during the implementation of the interdisciplinary mathematical modeling. This means that such an implementation cultivates the need, motivation, enthusiasm and curiosity of science and mathematics learning.

Because the students actively engaged in a real-life problem (as the context), the interdisciplinary mathematical modeling not only stimulated their awareness of environmental issues but also encouraged them to behave responsibly towards their close environments. Moreover, through a "need-to-know" basis, it seems to have empowered their conceptual understanding/meaningful learning levels (Lesh et al., 2000; Özgen, 2013; Remijan, 2017). For example, the students had learned the concepts "re-use, pollution, environmental protection, energy saving, global warming and reducing" to think about their mathematical models and problem-solving strategies. That is, the interdisciplinary mathematical modeling not only afforded them to acquire the targeted environmental concepts/issues but also somewhat supported their arguments (see Table 1). Moreover, given the themes and related categories (see Table 1), the students acted as responsible citizens for the environmental issue under investigation (e.g., Çalık, 2009; Çalik et al., 2014; Deveci \& Karteri, 2021) and strived to use their learning capacities of scientific investigation, scientific communication, and scientific conceptualization (Çalik et al., 2014, 2015; Doğan et al., 2019). To sum up, interdisciplinary mathematical modeling, which purposes to intertwine different disciplines with each other, equips students with the $21^{\text {st }}$ century skills such as inquiry, critical thinking, and innovative thinking. Further, because it enables students to associate content knowledge/conceptual understanding of any discipline with daily life issues, it also stimulates their interest in STEM career/education (Özgen, 2013; Remijan, 2017).

\section{Conclusions and Implications}

In light of the research results, it can be concluded that the interdisciplinary mathematical modeling, as an alternative pedagogical approach, is applicable for embedding relevant environmental concepts/issues within mathematical modeling. Further, it has a great potential at dealing with a common belief "science and mathematics come in useful at schools" since it advocates meaningful/context-based learning via real-life problems. Furthermore, the seventh-grade students' awareness of the environmental issue (e.g., plastic bottles) and possible solutions can be viewed as an indicator of their environmental responsibilities. Lastly, it can be deduced that engaging in real-life problems through the interdisciplinary mathematical modeling challenges conventional/procedural problem-solving habits only concentrating on clear-cut, intangible and unrealistic solutions. 
PROBLEMS

OF EDUCATION IN THE $21^{\text {st }}$ CENTURY Vol. 79 , No. 3, 2021

422

Even though the present research is part of an extensive project, it only presents the preliminary results of the problem "Building environmentally friendly constructions with plastic bottles." This may be seen as a limitation of the current research. Further research should be undertaken to conduct the interdisciplinary mathematical modeling of such environmental issues as waste of water, wastepaper, thermal insulation. Similarly, although the students modeled their mathematical/mental solutions, they did not build a playhouse in their schools. This may be viewed as another limitation of the current research. For this reason, future research should enable students to build their own playhouses in their schools or social areas. Such a follow-up research may provide invaluable insights about their environmental awareness and environmental management. Because 6 students and 2 teachers participated in the current research, the interdisciplinary mathematical modeling ought to be tested with a larger sample or pre/post experimental research design. Since the current research illustrates an alternative pedagogy to integrate science/environmental education into mathematics, it may be used to facilitate dissemination and applicability of the STEM education.

\section{Declaration of Interest}

Authors declare no competing interest.

\section{Acknowledgements}

This research was funded by the Scientific and Technological Research Council of Turkey (TUBITAK) (Grant No: 117K169). The authors would like to thank the project team, participants, and teachers for their kind efforts.

\section{References}

Atmaca, A. C., Kiray, S. A., \& Colakoglu, M. H. (2020). An examination of teachers' sustainable development awareness in terms of branches, genders, ages, and years of service. Problems of Education in the 21st Century, 78(3), 342-358. https://doi.org/10.33225/pec/20.78.342

Berry, J., \& Houston, K. (1995). Students using posters as a means of communication and assessment. Educational Studies in Mathematics, 29(1), 21-27.

Bilianska, M., \& Yaroshenko, O. (2020). Ability to foster schoolchildren's ecological literacy as a result of prospective biology teachers' professional training. Problems of Education in the 21st Century, 78(6), 907-919. https://doi.org/10.33225/pec/20.78.907

Cedere, D., Birzina, R., Pigozne, T., \& Vasilevskaya, E. (2020). Perceptions of today's young generation about meaningful learning of STEM. Problems of Education in the 21st Century, 78(6), 920-932. https://doi.org/10.33225/pec/20.78.920

Çalık, M. (2009). An integrated model for environmental education in Turkey. In N. Taylor, R. K. Coll, M. Littledyke \& C. Eames (Eds.), Environmental education in context: An international perspective of the development and implementation of environmental education and its impact on student knowledge, attitudes and behaviour (pp. 109-122). Sense Publishers.

Çalık, M. \& Aytar, A. (2013). Investigating prospective primary teachers' pedagogical content knowledge of "effect of human on environment" subject in the process of teaching practice. Educational Sciences: Theory \& Practice, 13(3), 1599-1605. https://doi.org/10.12738/estp.2013.3.1649

Çalık, M., \& Eames, C. (2012). The significance of national context: A comparison of environmental education in Turkey and New Zealand. Asia Pacific Education Researcher, 21(3), 423-433.

Çalik, M., Ebenezer, J., Özsevgeç, T., Küçük, Z. \& Artun, H. (2015). Improving science student teachers' self-perceptions of fluency with innovative technologies and scientific inquiry abilities. Journal of Science Education and Technology, 24(4), 448-460. https://dx.doi.org/10.1007/s10956-014-9529-1

Çalik, M., Özsevgeç, T., Ebenezer, J., Artun, H., \& Küçük, Z. (2014). Effects of 'environmental chemistry' elective course via technology embedded scientific inquiry model on some variables. Journal of Science Education and Technology, 23(3), 412-430. https://dx.doi.org/10.1007/s10956-013-9473-5 
Çalik, M., Turan, B. \& Coll, R.K. (2014). A cross-age study of elementary student teachers' scientific habits of mind concerning socioscientific issues. International Journal of Science and Mathematics Education, 12, 1315-1340. https://doi.org/10.1007/s10763-013-9458-0

Davison, D. M., Miller, K. W., \& Metheny, D. L. (1995). What does integration of science and mathematics really mean? School Science and Mathematics, 95(5), 226-230.

Dewanti, S. S., Kartowagiran, B., Jailani, \& Retnawati, H. (2020). Lecturers' experience in assessing 21 st-century mathematics competency in Indonesia. Problems of Education in the 21st Century, 78(4), 500-515. https://doi.org/10.33225/pec/20.78.500

Deveci, İ. \& Karteri, İ. (2021). Context-based learning supported by environmental measurement devices in science teacher education: A mixed method research. Journal of Biological Education. https://doi.org/10.1080/00219266.2020.1821083

Doğan, M.F., Gürbüz, R., Çavuş-Erdem, Z. \& Şahin, S. (2019). Using mathematical modeling for integrating stem disciplines: A theoretical framework. Turkish Journal of Computer and Mathematics Education, 10(3), 628-653. https://doi.org/10.16949/turkbilmat.502007

Er Nas, S., \& Çalık, M. (2018). A cross-age study of science student teachers' conceptual understanding of soil erosion. Problems of Education in the 21st century, 76(5), 601-619. https://doi.org/10.33225/pec/18.76.601

Gürbüz, R., Çavuş Erdem, Z., Şahin, S., Temurtaş, A., Doğan, C., Doğan, M.F., Çalık, M. \& Çelik, D. (2018). Bir disiplinler arası matematiksel modelleme etkinliğinden yansımalar [Reflections from an interdisciplinary mathematical modeling activity]. Adiyaman University Journal of Educational Sciences, Special Issue, 1-22. http://dx.doi.org/10.17984/adyuebd.463270

Gürbüz, R., Temurtaş, A., Doğan, M.F., Çalık, M. \& Çelik, D. (2019). Matematik ve fen bilimleri ögretmenlerinin matematiksel modelleme anlayışlarındaki değişimin incelenmesi [Investigating changes in mathematics and science teachers' understanding of mathematical modelling]. Paper presented at 4th International Symposium of Turkish Computer and Mathematics Education, 2628 September, İzmir, Turkey.

Hair, J. F. Jr., Black, W. C., Babin, B. J., Anderson, R. E., \& Tatham, R. L. (2006). Multivariate data analysis (6th ed.). Prentice-Hall International.

Herdem, K. \& Ünal, İ. (2018). STEM eğitimi üzerine yapılan çalışmaların analizi: Bir meta-sentez çalışması [Analysis of studies on STEM education: A meta-synthesis study]. Marmara University Atatürk Education Faculty Journal of Educational Sciences, 48(48), 145-163. http://dx.doi.org/10.15285/maruaebd.345486

Iliopoulou, I. (2018a). Children's thinking about environmental issues. Educational Research, 60(2), 241254. https://doi.org/10.1080/00131881.2018.1453753

Iliopoulou, I. (2018b). How young children think they can act for the environment: The case of forest and waste. Education 3-13, 46(3), 249-263. https://doi.org/10.1080/03004279.2016.1236829

Merriam, S.B. (1988). Case study research in education. Jossey-Bass.

Milli Eğitim Bakanlığı (2016). STEM eğitimi raporu [A report of STEM Education]. Ankara: Milli Eğitim Bakanlığı Yayınları.

Montgomery, D. R. (2007). Soil erosion and agricultural sustainability. Proceedings of the National Academy of Sciences of the United States of America, 104(33), 13268-13272.

Lesh, R., \& Doerr, H. M. (2003). Foundations of a models and modeling perspective on mathematics teaching, learning, and problem solving. In R. Lesh, \& H. M. Doerr (Eds.), Beyond constructivism: Models and modeling perspectives on mathematics problem solving, learning, and teaching (pp. 3-33). Lawrence Erlbaum.

Ormanc1, Ü. (2020). Thematic content analysis of doctoral theses in STEM education: Turkey context. Journal of Turkish Science Education, 17(1),126-146. https://dx.doi.org/10.36681/tused.2020.17

Özgen, K. (2013). Mathematical connection skill in the context of problem solving: The case of preservice teachers. Education Sciences, 8(3), 323-345.

Remijan, K. W. (2017). Project-based learning and design-focused projects to motivate secondary mathematics students. Interdisciplinary Journal of Problem-Based Learning, 11(1), 1-14.

Ültay, N., \& Çalik, M. (2016). A comparison of different teaching designs of 'acids and bases' subject. Eurasia Journal of Mathematics, Science and Technology Education, 12(1), 57-86. https://doi.org/10.12973/eurasia.2016.1422a

Yin, R. K. (2003). Case study research: Design and methods ( $3^{\text {rd }}$ ed.). Sage publications. 
Ramazan GÜRBÜZ, Muammer ÇALIK. Intertwining mathematical modeling with environmental issues

PROBLEMS

OF EDUCATION

IN THE $21^{\text {st }}$ CENTURY

Vol. 79 , No. 3, 2021

424

Received: March 11, 2021

Accepted: June 03, 2021

Cite as: Gürbüz, R., \& Çalık, M. (2021). Intertwining mathematical modeling with environmental issues. Problems of Education in the $21^{\text {st }}$ Century, 79(3), 412-424. https://doi.org/10.33225/pec/21.79.412

Ramazan Gürbüz

Professor of Mathematics Education, Department of Mathematics and Science Education, Faculty of Education, Adıyaman University, Adıyaman/ Turkey.

E-mail: rgurbuz@outlook.com

Website: https://www.researchgate.net/profile/Ramazan_Guerbuez ORCID: https://orcid.org/0000-0002-2412-5882

Muammer Çalık

(Corresponding author)
Professor of Chemistry Education, Department of Elementary Teacher Education, Fatih Faculty of Education, Trabzon University, Trabzon/Turkey E-mail: muammer38@hotmail.com

Website: https://www.researchgate.net/profile/Muammer-Calik ORCID: https://orcid.org/0000-0001-8323-8783 